\title{
PELATIHAN PENINGKATAN OMSET PENDAPATAN INDUSTRI RUMAHAN NASI KRAWU DI KABUPATEN GRESIK
}

\author{
Titus Kristanto ${ }^{1}$, Nanang Fakhrur Rozi ${ }^{2}$, Eka Cahya Muliawati ${ }^{3}$, Rachman Arief ${ }^{4}$, Syaiful \\ Hidayat $^{5}$, Halimatus Sadiyah ${ }^{6}$ \\ ${ }^{I}$ Fakultas Teknologi Informasi dan Industri, Prodi Rekayasa Perangkat Lunak, Institut Teknologi \\ Telkom Surabaya \\ ${ }^{2,4}$ Fakultas Teknik Elektro dan Teknologi Informasi, Prodi Teknik Informatika, Institut Teknologi \\ Adhi Tama Surabaya \\ ${ }^{3}$ Fakultas Teknik Industri, Prodi Teknik Kimia, Institut Teknologi Adhi Tama Surabaya \\ ${ }^{5}$ Fakultas Teknik, Prodi Teknik Informatika, Universitas Dr. Soetomo Surabaya \\ ${ }^{6}$ Nasi Krawu Buk Tiban Gresik \\ Email: tintus.chris@gmail.com,nfrozy@gmail.com, echa.ekacahya@gmail.com, \\ ramanarif@gmail.com, syaifulits@gmail.com, halimahmulyo@gmail.com
}

\begin{abstract}
In the millennial era 4.0, the growth of the home industry is growing more rapidly with the development of information technology, thus making needs increase and create new business opportunities. One of the new business opportunities is the krawu rice business. Krawu rice is a typical food from Gresik Regency. The krawu rice home industry is a partner of a community service activity named Nasi Krawu Buk Tiban. The problem that occurs in the community service partners is the marketing of krawu rice that is still around the Nasi Krawu Buk Tiban environment and marketing through the internet media. The method used is to provide training in the form of online media marketing and social media assistance. The result of community service activities can increase krawu rice revenue turnover, can operate and promote krawu rice marketing through online media and social media.
\end{abstract}

Keywords: Training, Krawu Rice, Online Media, Social Media.

\begin{abstract}
$\overline{\text { Abstrak : Di era milenial 4.0, pertumbuhan industri rumahan berkembang semakin pesat }}$ dengan adanya perkembangan teknologi informasi, sehingga membuat kebutuhan menjadi meningkat dan menciptakan peluang bisnis baru. Salah satu peluang bisnis baru adalah usaha nasi krawu. Nasi krawu merupakan makanan khas dari Kabupaten Gresik. Industri rumahan nasi krawu merupakan mitra dari kegiatan pengabdian yang bernama Nasi Krawu Buk Tiban. Permasalahan yang terjadi pada mitra pengabdian adalah pemasaran nasi krawu yang masih di sekitar lingkungan Nasi Krawu Buk Tiban dan pemasaran melalui media internet. Metode yang digunakan adalah memberikan pelatihan berupa pendampingan pemasaran media online dan media social. Hasil dari kegiatan pengabdian adalah dapat meningkatkan omset pendapatan nasi krawu, dapat mengoperasikan dan mempromosikan pemasaran nasi krawu melaui media online dan media social.
\end{abstract}

Kata Kunci: Pelatihan, Nasi Krawu, Media Online, Media Sosial. 


\section{PENDAHULUAN}

Nasi krawu merupakan makanan khas asli dari Kabupaten Gresik (Wikipedia, 2019). Bahan baku utama dari nasi krawu adalah daging sapi, cabai, kelapa, dan bumbu-bumbu lain pendukung produk nasi krawu. Supply daging sapi dan bahan baku yang lain didapatkan dari pasar tradisional (Kusdarini \& Yuwanto, 2018).

Keunggulan nasi kwau terlihat dari cara penyajian yang unik dan menarik, tapi terkesan sangat tradisional. Cara penyajian dilakukan menggunakan alas daun pisang. Nasi pulen merupakan sajian dari nasi krawu dengan penambahan semur daging, sayatan daging, serundeng, jeroan sapi dan sambal terasi. Sajian nasi krawu dapat dilihat pada Gambar 1.

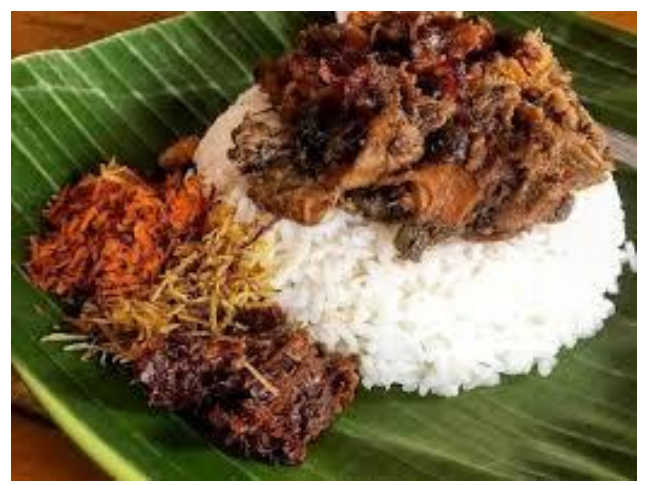

\section{Gambar 1 Nasi krawu}

Salah satu industri rumahan nasi krawu yang terkenal di Kabupaten Gresik adalah Nasi Krawu Buk Tiban, seperti terlihat pada Gambar 2 (Kholidah, 2016). Nasi Krawu Buk Tiban merupakan Mitra Pengabdian. Lokasi Mitra Pengabdian berada di Jl. Veteran No. 118 Gresik.

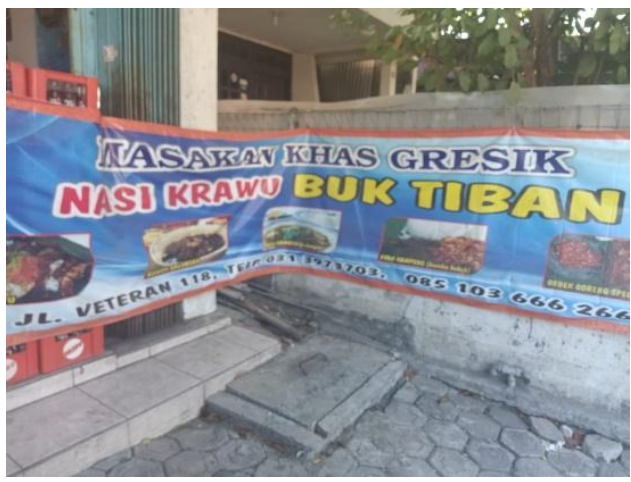

\section{Gambar 2 Lokasi Nasi Krawu Buk Tiban}

Beberapa sajian yang dihidangkan selain nasi krawu adalah nasi rawon balungan, soto madura balungan, dan ayam kampung bumbu bebek.

Beberapa fokus yang dilakukan tim pengabdian ke mitra pengabdian berdasarkan hasil pengamatan adalah (Kristanto et al., 2019)

1. Pemasaran yang dilakukan masih di sekitar Gresik.

2. Keterbatasan modal dalam memasarkan produk nasi krawu ke media internet dan media social.

3. Pengemasan nasi krawu masih menggunakan kertas pembungkus nasi dengan tulisan nama "Nasi Krawu Buk Tiban”.

Berdasarkan hasil kesepatan bersama antara tim pengabdian dan mitra pengabdian adalah membuatkan akun media internet dan media social nasi krawu, serta desain kemasan. Solusi yang ditawarkan adalah berupa pelatihan memasarkan produk nasi krawu secara online melalui media internet dan media social, serta mengajarkan membuat desain kemasan nasi krawu agar lebih menarik dan tahan lama. 


\section{METODE PELAKSANAAN}

Berdasarkan permasalahan yang dihadapi oleh mitra pengabdian berupa pemasaran produk nasi krawu melalui media internet dan media social. Metode yang digunakan tim pengabdian berupa pendampingan dan pelatihan (Kristanto et al., 2018). Solusi yang ditawarkan berupa pelatihan pemasaran media online, media social, dan promosi berbayar melalaui Facebook Ads dan Instagram Ads (Indrawati et al., 2017).

Pada Gambar 3 menunjukkan tahapan metode pelaksanaan dari kegiatan pengabdian.

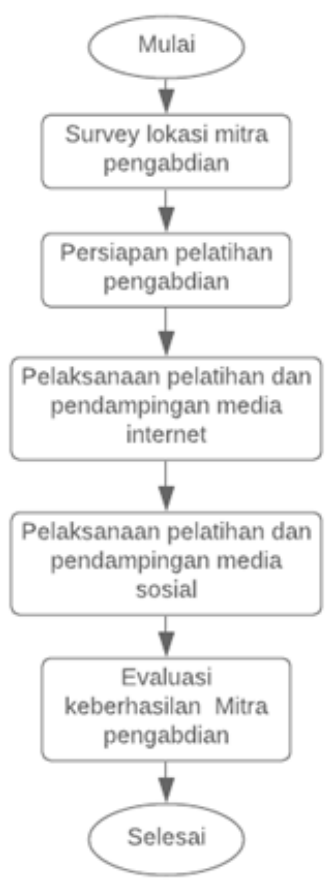

\section{Gambar 3 Metode pelaksanaan kegiatan pengabdian}

Berikut penjelasan dari Gambar 3 :

1. Survey lokasi mitra pengabdian.
Tim pengabdian melakukan surver lokasi ke Mitra Pengabdian (Nasi Krawu Buk Tiban Gresik), sebagai tahap awal dan menanyakan bersedia menjadi mitra pengabdian, sekaligus menanyakan permasalahan apa saja yang sering terjadi pada mitra pengabdian.

2. Persiapan pelatihan pengabdian

Setelah survey awal ke Mitra Pengabdian (Nasi Krawu Buk Tiban Gresik), tim pengabdian melakukan serangkaian kegiatan berupa mempersiapkan materi pelatihan, beserta peralatan pelatihan. Tim pengabdian melakukan pembagian tugas tim pengabdian, termasuk mempersiapkan kuesioner sebagai umpan balik dari kegiatan pengabdian.

3. Pelaksanaan pelatihan dan pendampingan media internet.

Kegiatan pelatihan pengabdian dilakukan selama 1 hari terbagi menjadi 2 topik pelatihan yaitu pelatihan dan pendampingan media internet dan media social, serta pendampingan membuat desain kemasan. Pada pelatihan dan pendampingan media internet, tim pengabdian memperkenalkan ke mitra pengabdian bagaimana cara bertransaksi di media internet, termasuk cara memesan dan order nasi krawu.

4. Pelaksanaan pelatihan dan pendampingan media social.

Pada pelatihan dan pendampingan media social, tim pengabdian mengajarkan ke mitra pengabdian bagaimana cara berpromosi di media social. Media social sebagai tempat promosi adalah Facebook dan Instagram. 
5. Evaluasi tangka keberhasilan

Pada tahap akhir yaitu evaluasi tingkat keberhasilan, tim pengabdian melakukan pemantauan dan analisis dari hasil pemasaran media internet dan media social, serta mengevaluasi hasil pelatihan yang sudah dilaksanakan selama 1 hari diikuti sekitar 10 orang pegawai dan pemilik Nasi Krawu Buk Tiban.

\section{HASIL DAN PEMBAHASAN}

Kegiatan pelatihan dan pendampingan pengabdian masyarakat dilaksanakan selama 1 hari pada hari Jumat 12 Juli 2019. Lokasi kegiatan berada di Nasi Krawu Buk Tiban, Jl. Veteran Gresik. Tim pengabdian masyarakat diikuti oleh dosen dan dibantu oleh mahasiswa (Kristanto et al., 2019), seperti terlihat pada Gambar 4.

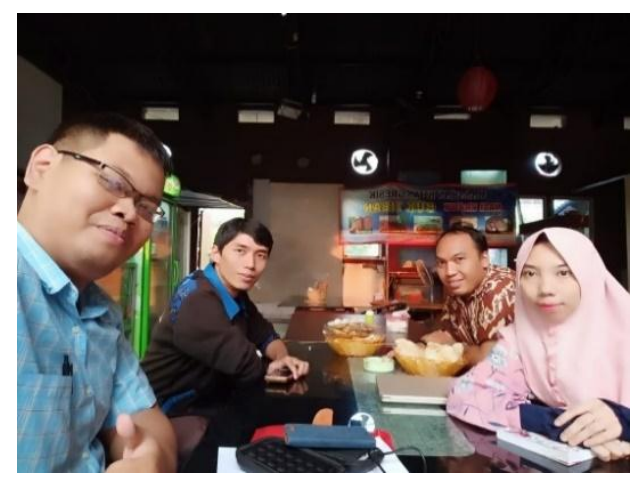

\section{Gambar 4 Tim pengabdian masyarakat}

Sebelum kegiatan pengabdian dimulai, tim pengabdian melakukan survey terlebih dahulu, permasalahan apa saja yang terjadi pada mitra pengabdian. Dari hasil survey didapatkan masalah pemasaran di media online dan media social, serta kemasan nasi krawu. Sekaligus memutuskan jadwal pelaksanaan kegiatan pelatihan pengabdian.

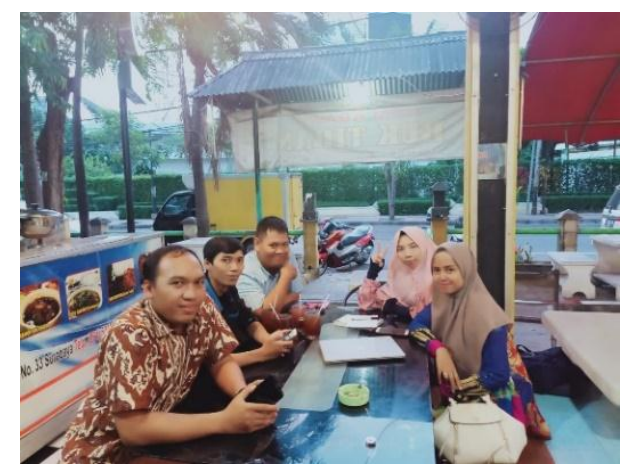

Gambar 5 Diskusi awal dengan mitra pengabdian

Setelah mendapatkan tanggal dan waktu yang sudah ditentukan, maka tim pengabdian membuatkan modul pelatihan tentang pemasaran media internet dan media social. Tim pengabdian juga membuatkan kuesioner dan melakukan koordinasi antar tim pengabdian.

Pada saat kegiatan pelatihan pengabdian berlangsung, tim pengabdian melakukan pendampingan ke mitra pengabdian cara memasarkan produk nasi krawu ke media internet (Gambar 6) dan media social (Gambar 7). Terlihat Mitra pengabdian terlihat antusias mengikuti kegiatan pelatihan.

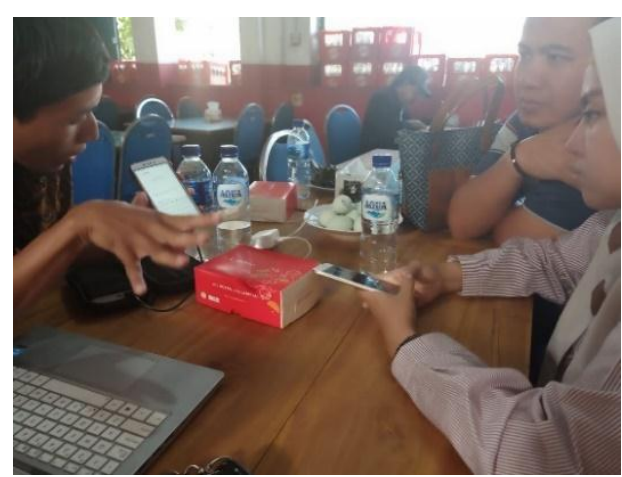

Gambar 6 Pelatihan Media Internet 


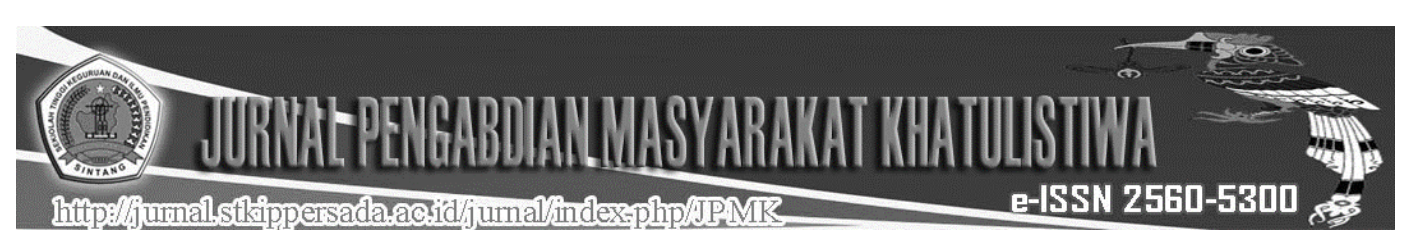

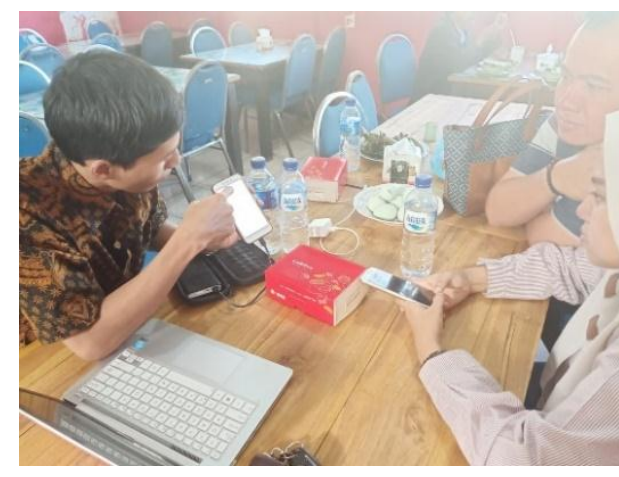

\section{Gambar 7 Pelatihan Media Sosial}

Pelatihan kegiatan pengabdian selain diikuti pemilik usaha nasi krawu, pelatihan juga diikuti oleh karyawan atau pegawai usaha nasi krawu (Gambar 8). Tidak lupa, tim pengabdian berfoto Bersama dengan pemilik Nasi Krawu Buk Tiban (Gambar 9).

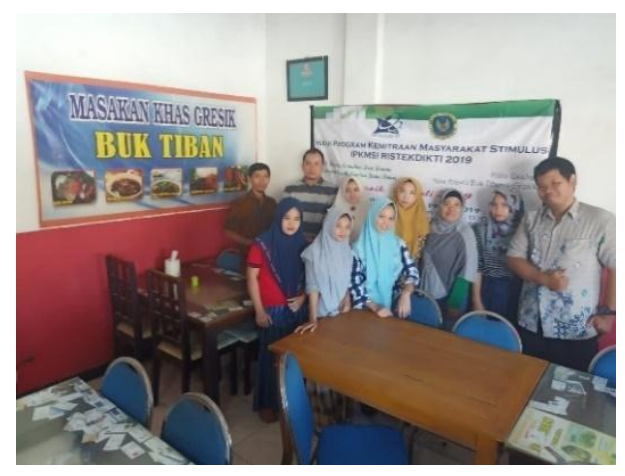

\section{Gambar 8 Peserta Pelatihan Pengabdian}

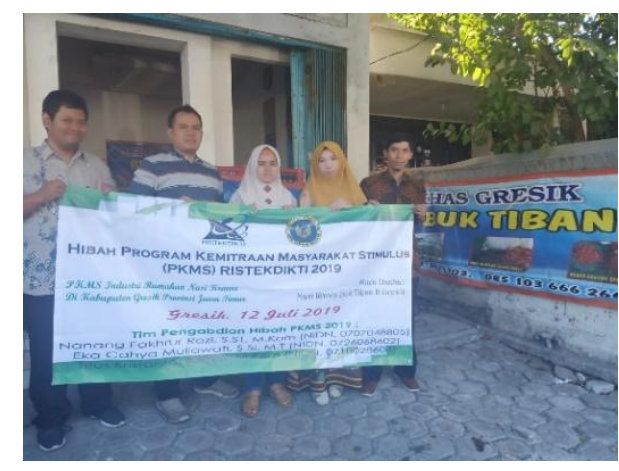

Gambar 9 Foto Bersama dengan pemilik Nasi Krawu Buk Tiban
Pada Gambar 10 dan Gambar 11, merupakan tampilan Facebook Ads dan Instagram Ads Nasi Krawu Buk Tiban. Pada Gambar 12 dan Gambar 13, merupakan tampilan desain kemasan nasi krawu bentuk kertas dan bentuk kotak.

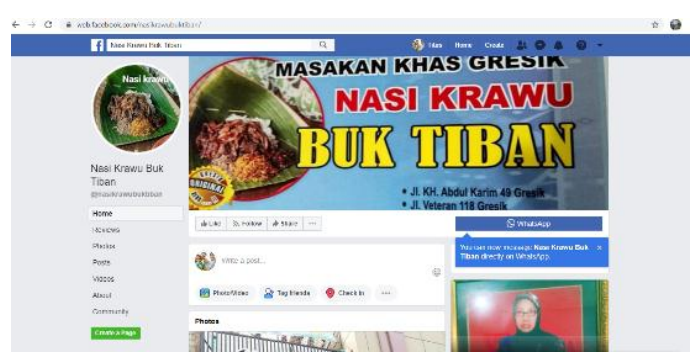

Gambar 10 Tampilan Facebook Ads

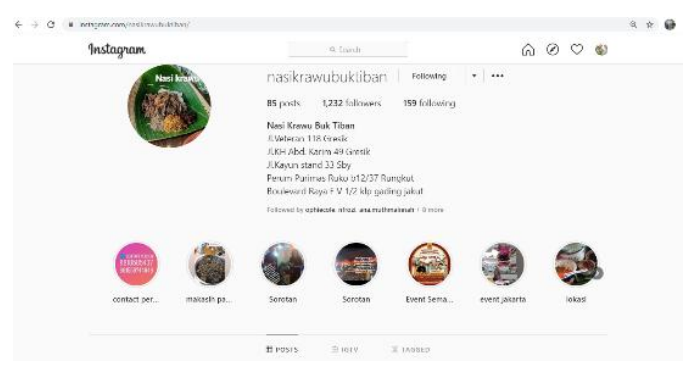

Gambar 11 Tampilan Instagram Ads

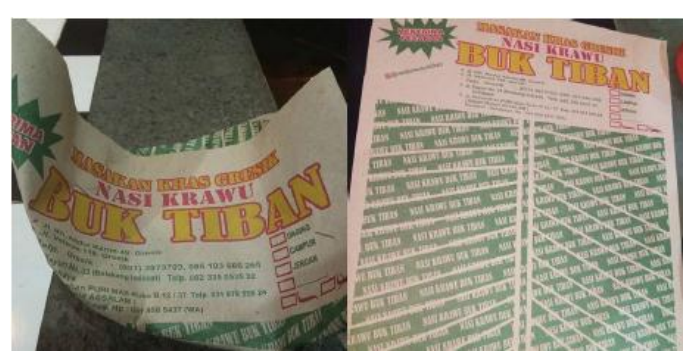

Gambar 12 Tampilan desain kemasan bentuk kertas 


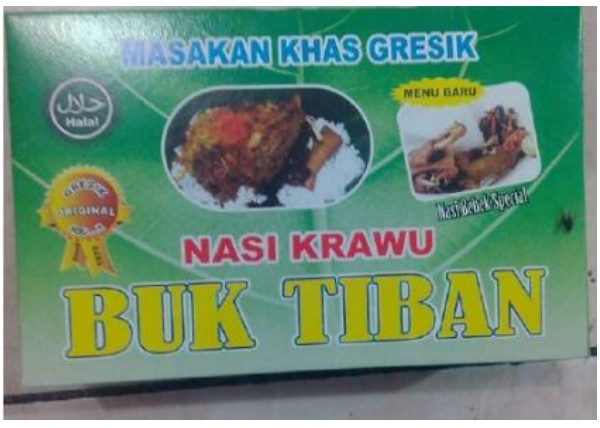

Gambar 13 Tampilan desain kemasan bentuk kotak

Selain membuat Facebook Ads dan Instagram Ads, tim pengabdian juga membuatkan web media internet sebagai pemasaran online. Tujuan dari dibuatkan web media internet adalah pangsa pasar Nasi Krawu Buk Tiban semakin berkembang dan semakin meluas seantero Indonesia Raya. Media internet pemasaran online dapat diakses di https://nasikrawubuktiban.com/ Seperti terlihat pada Gambar 14.

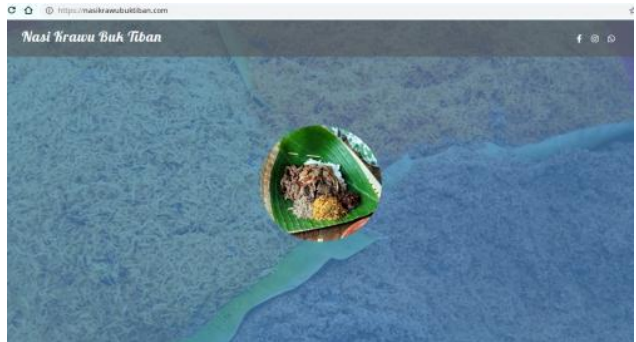

\section{Gambar 14 Media internet pemasaran online}

Pada Gambar 15 dan Gambar 16 merupakan testimoni dari pemilik dan pengunjung Nasi Krawu Buk Tiban.

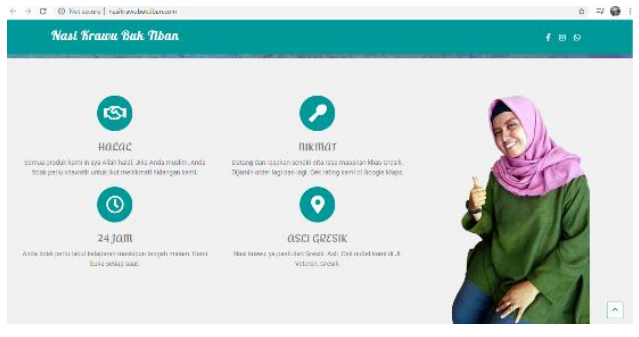

\section{Gambar 15 Testimoni dari Pemilik Nasi Krawu Buk Tiban}

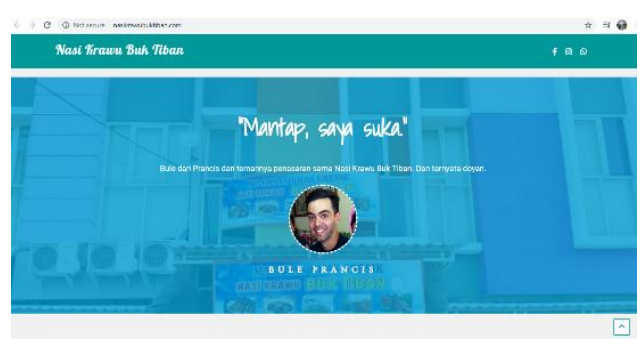

Gambar 15 Testimoni dari Pengunjung Nasi Krawu Buk Tiban

\section{SIMPULAN}

Berdasarkan dari kegiatan pelatihan pengabdian yang sudah dilaksanakan, maka dapat disimpulkan adalah :

1. Tingkat partisipasi dan antusias dari Mitra Pengabdian memberikan dampak positif dari kegiatan pelatihan dan pendampingan pemasaran online produk nasi krawu ke media internet dan media social.

2. Percobaan promosi online melalui Facebook Ads dan Instagram Ads belum mencapai hasil dari target produk nasi krawu yang diharapkan.

\section{UCAPAN TERIMA KASIH}

Tim pengabdian masyarakat mengucapkan terima kasih kepada Direktorat Riset dan Pengabdian Masyarakat (DRPM) Kementerian Riset, Teknologi, dan Pendidikan Tinggi (Kemenristekdikti) yang sudah mempercayakan untuk 
membiayai pendanaan Hibah Program Kemitraan Masyarakat Stimulus (PKMS) Tahun Anggaran 2019. Tim pengabdian juga berterima kasih kepada mitra pengabdian yang sudah bersedia menjadi mitra dari kegiatan pengabdian masyarakat dan semua pihak yang sudah terlibat dalam pelaksanaan kegiatan pengabdian masyarakat Hibah PKMS 2019.

\section{DAFTAR RUJUKAN}

Indrawati, K. A. P., Sudiarta, N. I., \& Suardana, W. I. (2017). Efektivitas Iklan Melalui Media Sosial Facebook Dan Instagram Sebagai Salah Satu Strategi Pemasaran Di Krisna Oleh-Oleh Khas Bali. Analisis Pariwisata, 17(2), 78-83. https://ojs.unud.ac.id/index.php/jap /article/view/36484

Kholidah, F. N. (2016). Pengaruh Kualitas Produk Dan Harga Terhadap Keputusan Pembelian Nasi Krawu Di Kota Gresik. Jurnal Pendidikan Tata Niaga (JPTN), 3(3), 1-10.

Kristanto, T., Rahmawati, D., Nurdin, A., Putro, F. W., Wicaksono, A. Y., Sholik, M., Metahelgia, Pratiwi, S. R., \& Sholeh, L. (2019). Pelatihan Keterampilan Web Design Bagi Siswa SMK Negeri 1 Surabaya. Randang Tana : Jurnal Pengabdian Masyarakat, 2(2), 153-160.

Kristanto, T., Ratniarsih, I., Laksmiyanti, D. P. E., Sukarnaen, \& Sabtalistia, Y. A. (2018).

Pelatihan dan Penyuluhan Usaha Otak-Otak Ikan di Perumahan Dinas PT KAI Kota Surabaya. $J$ Dinamika: : Jurnal Pengabdian Masyarakat, 3(2), 176-179.
Kusdarini, E., \& Yuwanto, S. H. (2018). Pendampingan UKM Produk Nasi Krawu dengan Perbaikan Proses Produksi dan Kemasan Produk untuk Meningkatkan Penjualan. Jurnal Pengabdian LPPM Untag Surabaya, 03(01), 79-83.

Wikipedia. (2019). Nasi Krawu. 